\title{
Modelling the Growth Trend of the Iron and Steel Industry: Case for Uganda
}

\author{
Abraham J. B. Muwanguzi*, Patrick Olowo, Hennery Sebukeera, Asuman Guloba, Damir Mezulic, \\ Paolo Bonci, Joseph Muvawala
}

National Planning Authority, Kampala, Uganda

Email: ^ajbm@kth.se, *abraham.muwanguzi@npa.go.ug, patrick.olowo@npa.go.ug, hennery.sebukeera@npa.go.ug, lucacecilia9086@gmail.com, paolo.bonci@fastwebnet.it, asuman.guloba@npa.go.ug, joseph.muvawala@npa.go.ug

How to cite this paper: Muwanguzi, A. J. B., Olowo, P., Sebukeera, H., Guloba, A., Mezulic, D., Bonci, P., \& Muvawala, J. (2020). Modelling the Growth Trend of the Iron and Steel Industry: Case for Uganda. American Journal of Industrial and Business Management, 10, 1640-1654.

https://doi.org/10.4236/ajibm.2020.109104

Received: August 18, 2020

Accepted: September 26, 2020

Published: September 29, 2020

Copyright ( 2020 by author(s) and Scientific Research Publishing Inc. This work is licensed under the Creative Commons Attribution International License (CC BY 4.0).

http://creativecommons.org/licenses/by/4.0/

\begin{abstract}
The iron and steel industry is critical in driving the industrialisation agenda of $3^{\text {rd }}$ world economies like Uganda and there is need to understand its growth trends in order to inform the required investments in the medium to long-term. The Capability Model and the system of equations of the Dynamic Stochastic General Equilibrium Models (DSGEs) were employed to forecast the growth trends of Uganda's iron and steel production and consumption (2019-2024). The results of the study show that liquid steel production can be increased from 210,000 tonnes to 1.1 million tonnes per annum by 2024 with measures of industry sustenance and infrastructure investments put in place. Even though there is projected to be an initial fluctuation between 2020 and 2022, due to interruptions during the period of technological upgrade, there is on average, a distinctive steel production growth over the next 5 years. The study recommends fast-tracking the highlighted public and private sector investments in domestic iron and steel production.
\end{abstract}

\section{Keywords}

Economic Model, DSGEs, Economic Growth, Economic Development, NPA, Uganda

\section{Introduction}

Iron and steel are among the most sought-after commodities especially for structural purposes due to a number of reasons among which are the good mechanical properties, low production cost associated with it and high strength in relation to its weight. Basically, both are easily recyclable for the production of new products. Ultimately, the use of iron and steel-based products has come to be associated with the industrialisation of economies for decades (Ruth, 2004). 
Since the onset of the industrial revolution, iron and steel became an important component of the industry and by 1967, iron ore had become the third largest trade item on the world market, after petroleum and wheat (The Iron Ore of the Earth, 1967). The world's total mined raw iron ore was then 600 million metric tonnes. In 1979, the world production of iron ore was about 900 million tonnes and the World Bank estimated that it would increase by about 300 million tonnes in the next eight years (Banks, 1979). In order to ensure proper planning for the supply of iron ore, given the increasing demand for iron and steel, models were developed to predict future demands.

In 1983, Hashimoto presented a model for the world iron and steel economy termed the WISE model, which projected global market situations in future benchmark years between 1980-95 (Hashimoto, 1983). Taking various factors into consideration and using the UN Economic Commission for Europe and The International Iron and Steel Institute figures for iron consumption between 1975 and 1984, the model projected that the steel consumption would reach 759 million tonnes by 1995 .

Following the basic conceptual frame work offered by Smithson in 1979, Stephen developed an econometric model of the world trade in iron and steel to present an econometric analysis of the world's changing patterns in the iron ore and steel industry (Stephen, 1997). Stephen analysed the world iron and steel trade in eleven regions from the various continents, using data from the International Iron and Steel Institute and the International Monetary Fund between the periods 1972-92. In the model results, it was estimated that the world's steel consumption would increase by 90.3 million tonnes from 726.5 in 1994 to 816.8 million tonnes by 2000 . The 90.3 million tonne increase was to correspond to an increase in iron ore demand of 122.2 million tonnes per year by 2000 from 947.8 in 1994 to 1070 million tonnes by the year 2000 .

At the end of the twentieth century, the worldwide production of crude steel was standing at 900 million tonnes and in 2008, it was estimated that it would reach 1 billion tonnes within the first two decades. Likewise, iron ore consumption for steelmaking was standing at 850 million tonnes at the end of the twentieth century and was estimated that it will be more than 1.3 billion tonnes over the first quarter of the century (Katrak, 2008). By 2015, World crude steel production reached 1.621 billion tonnes (World Steel Association, 2016) with iron ore consumption standing at 1.824 billion tonnes (World Steel Association, 2008).

It can thus be noted that since the 1960s, iron and steel consumption has been on an upward consistent trend, with corresponding increases in the consumption of iron ore and this has mostly been spurred by the growth in the world population over the decades. Today, 1869 million tonnes of crude steel is being produced with $2 \%$ being used in domestic appliances, $3 \%$ in electrical equipment, $5 \%$ in other transport, $10 \%$ in metal products, $16 \%$ in mechanical equipment and 52\% in building and infrastructure (World Steel Association, 2020a). With the world moving further up the ladder of economic growth and develop- 
ment, with many third world countries aspiring to become developed economies, the demand for iron and steel products will most probably continue on its upward trend.

Uganda aspires to become an upper middle-income country by 2040 and the national planning frameworks (National Planning Authority, 2013, 2010, 2015) have earmarked the development of the country's iron and steel industry, based on its existing iron ore deposits, among the key interventions to be used to achieve the desired vision. To encourage investment in this, the country banned the exportation of unprocessed iron ore in 2011, so as to promote value addition in the iron and steel sector and an analysis of the country's ore potential for this was carried out (Muwanguzi et al., 2020).

Uganda's importation of iron and steel products increased from USD 162 million in 2010 to USD 279 million in 2015 and currently stands at USD 369 million (International Trade Centre, 2019). The iron and steel trade deficit gap is large as imports are more than exports by $80 \%$ throughout the years. In order to aid the achievement of the plans that the country has, the National Planning Authority (NPA), the government planning agency, embarked on a study to assess the prevailing parameters that have informed and influenced the growth of the industry over the years, so as to make predictions of likely outcomes and influences over the planned years. Two (2) models were developed to project the iron and steel consumption over the next five years (2020-2025). This was done in order to understand the growth trends so as to inform required investment in the iron and steel industry and the national level infrastructure to meet the required demand and thus justify the investments.

\section{Methodology}

The study utilises both the Capability Model and the system of equations of the Dynamic Stochastic General Equilibrium Models (DSGEs) (Ohanian, Prescott, \& Stokey, 2009; Shantayanan \& Delfin, 1998) to make predictions of the likely scenario of growth of Uganda's iron and steel industry. The Capability Model was developed in the study based on figures of current steel production (2019), present installed capacity (which is at $35 \%$ utilisation) and planned investments in the industry the private sector. The DSGE models permit current values of variables to depend not only on past values but also on expectations of future values. All of the parameters used in the DSGE model are to predict the effects of steel sector growth on Uganda economic sectors as well as consumption and future investment based on historical time series data for 2001-2018. In general, DSGE models are multivariate time-series models that are used in macroeconomic policy analysis and forecasting (Jensen, Pedersen, Rutherford, \& Glenn, 2000; Keyzer \& Gunning, 1995; Dervis, de Melo, \& Robinson, 1989). These models are systems of equations that are typically derived from economic theory and as such, their parameters are often directly interpreted based on economic theory.

Generally, the standard parameters for the iron and steel market were eva- 
luated according to the present and future country situation. These parameters were related to the consumption of steel per person year by year and their sustainable growth is important for the iron and steel value chain. To this effect, the trend of the projected population growth in the country was assessed. To correctly calculate the steel consumed in the country, the imported quantities of iron and steel were taken into consideration and balanced with exports. Additionally, visits were made to the 17 iron and steel processing plants in the country to obtain information about their production statistics and future plans.

\subsection{The Theoretical Model}

In order to develop an Economic Model to assess the impact of the iron and steel industry on GDP, foreign currency earnings, demand and supply movements, the Klein model was modified (William, 2002), simplifying it and including parameters relative to the steel sector possible impacts.

Input data for Uganda's economic model was based on the following historical data:

1) Apparent steel consumption obtained from the World Bank (World Bank, 2020b), World Development Indicators Data Base (World Bank, 2020a), World Steel Association (World Steel Association, 2020b) and Trade Map Data Base (International Trade Centre, 2019).

2) All good consumed in Uganda except steel.

3) Investment in the steel sector as sum of loans and foreign + domestic investments.

4) Gross domestic product, production of steel, population growth, imports and export of iron and steel products which was obtained from Uganda Bureau of Statistics (UBOS) (Uganda Bureau of Statistics, 2019).

The model output includes the steel parameters of interest for the iron and steel industry referred to apparent data (which means that not only the imported and exported steel was considered but also the steel included in goods like for example cars, appliances, etc.).

The model uses a system of Equations (1,2 and 3) and identities (4 and 5) as shown below:

$$
\text { C_Steel } t_{t}=\alpha_{0}+\alpha_{1} G D P_{t}+\alpha_{2} \text { Pop }_{t}+\alpha_{3} C_{-} \text {Steel }_{t-1}+\alpha_{4} N_{\text {X_Steel }}+\alpha_{5} \text { Gov }_{t}
$$

In Equation (1), the Aggregate Consumption of steel at time $t\left(C_{-} s_{t e e}\right)$ is a linear function of the Gross Domestic Product $\left(G D P_{t}\right)$, the Population $\left(P o p_{t}\right)$, the Aggregate Consumption of steel at time $t-1\left(C_{-}\right.$steel $\left._{t-1}\right)$, the Net export of steel $\left(N X \_s t e e I_{t}\right)$ and the Government expenditure $\left(G o v_{t}\right)$.

$$
\text { C_Others }{ }_{t}=\beta_{0}+\beta_{1} C P I_{t}+\beta_{2} G D P \_p c_{t}+\beta_{3} N X \_ \text {Others }{ }_{t}
$$

In Equation (2), the aggregate consumption of other goods at time $t$ ( $C_{-}$other $\left.{ }_{t}\right)$ is a linear function of the Consumer Price Index $\left(C P I_{t}\right)$ that is a proxy for inflation, Gross Domestic Product per capita $\left(G D P_{-} p c_{t}\right)$ which is a proxy for income and the Net export of other goods $\left(N X_{-} \text {other }\right)_{t}$.

$$
\text { Inv_Steel }{ }_{t}=\gamma_{0}+\gamma_{1} R \_i n t_{t}+\gamma_{2} \text { Total_Inv }_{t-1}
$$


Equation (3) shows that aggregate investment in the steel sector at time $t$ $\left(\right.$ Inv_steel $\left.I_{t}\right)$ is a linear function of real interest rate $\left(R \_i n t_{t}\right)$, and total investment at time $t-1$ (Total_In $\left.v_{t-1}\right)$.

$$
G D P_{t}=C \_S t e e l_{t}+C \_ \text {Others }{ }_{t}+\text { Gov }_{t}+\text { Total_Inv } t_{t}+N X \_ \text {Others }{ }_{t}+N X \_ \text {Steel }(4)
$$

The representation in Equation (4) is an identity, and is the general equilibrium condition, for the Keynesian equation. It states that the economy's level of production $\left(G D P_{t}\right)$, depends on the Aggregate Consumption of steel ( $C_{-}$steel $\left._{t}\right)$, the Aggregate Consumption of other goods $\left(C_{-}\right.$other $\left.{ }_{t}\right)$, the Government expenditure $\left(\operatorname{Gov}_{t}\right)$, Total investment (in all economic sectors) (Total_Inv $)_{t}$, the Net export of other goods $\left(N X \_o t h e r_{t}\right)$ and the Net export of steel $\left(N X \_s t e e I_{t}\right)$.

$$
\text { Prod_Steel }_{t}=C_{-} \text {Steel }_{t}+N X_{-} \text {Steel }_{t}
$$

Equation (5) is an Identity showing the equilibrium condition for the production of steel (Prod_steel ${ }_{t}$ ) which depends on the aggregate consumption of steel $\left(C_{-}\right.$steel $\left._{t}\right)$ and the net export of steel $\left(N X_{\_}\right.$steel $\left._{t}\right)$.

\subsection{The Econometric Model}

Starting from the theoretical model presented above, an econometric model was built in order to estimate the values of $C_{-}$steel $_{t}, C_{-}$other, Inv_steel ${ }_{t}, G D P_{t}$ and Prod_steel in a dynamic way. Consequently, the econometric representation of the Equations (1) to (5) is given in Equations (6)-(10)

$$
\begin{aligned}
& c \_s t e e l_{t}=\alpha_{0}+\alpha_{1} g d p_{t}+\alpha_{2} \text { pop }_{t}+\alpha_{3} \text { __steel }_{t-1}+\alpha_{4} n x \_ \text {steel } t+\alpha_{5} \text { gov }_{t}+e_{t} \\
& \text { c_others }{ }_{t}=\beta_{0}+\beta_{1} c p i_{t}+\beta_{2} g d p \_p c_{t}+\beta_{3} n x \_ \text {others }{ }_{t}+e_{t} \\
& \text { inv_steel }{ }_{t}=\gamma_{0}+\gamma_{1} r \_i n t_{t}+\gamma_{2} \text { total_inv }_{t-1}+e_{t} \\
& g d p_{t}=c \_s t e e l_{t}+c \_o t h e r s_{t}+g o v_{t}+\text { total_inv } t_{t}+n x \_o t h e r s_{t}+n x \_s t e e l_{t} \\
& \text { prod_steel }_{t}=c \_s t e e l_{t}+n x \_s t e e l_{t}
\end{aligned}
$$

The exogenous variables are $g d p_{t}, p o p_{t}, c_{-} s_{t e e} t_{t-1}, n x_{-}$steel $_{t}, \operatorname{gov}_{t}, c p i_{t}, g d p_{-} p c_{t}$, $n x_{\text {oothers }}, r_{-}$int $_{t}$, and total_in $v_{t-1}$ while the endogenous variables are $c_{-}$steel $l_{t}$ $c_{-}$others $s_{t}$ and inv_steel. The assumptions required to run the economic model, keeping into account the specific country data relevant to population, government expenditure and investment, were:

1) Population growth trends followed the Uganda Bureau of Statistics projections up to 2040;

2) Government expenditure increases by 1 percent annually starting from 2019;

3) Total investment in the steel sector is obtained from the sum of outstanding loans to the metal sector (from UBOS data base (Uganda Bureau of Statistics, 2019)) and foreign direct investment calibrated to the metal sector, considering that half of it goes to the manufacturing sector; metal sector weights $8.3 \%$ of manufacturing sector (World Bank Data Base).

4) Government investment is assumed to increase by $2 \%$ annually starting 
from 2019.

5) Import and export of steel data starting in 2019 are assumed to be proportional to the average unitary value of steel import (finished product) in the period 2001-2018 as provided by UBOS.

As is commonly known, the DSGE model suffers from the endogeneity problem. Consequently, the three stage Least Squares method was employed to overcome this bias. The time period from 2001 to 2018 was considered to estimate the forecast predicted values. The model output includes the steel parameters of interest for the iron and steel industry referred to as apparent data (i.e. it considers in total, the amount of imported and exported steel and also steel quantities included in goods like for example cars, appliances, etc.) integrated with the actual data collected during the visit to steel players in Uganda.

\section{Results and Discussion}

Uganda's population growth trends and the import/export of iron and steel products through the years are given in Figure 1 and Figure 2, respectively (Uganda Bureau of Statistics, 2019). It can be noted from the figures that the country's population has been growing over the years and is projected to reach 53 million by 2030. The imports of iron and steel have correspondingly been increasing, which is probably spurred by the increasing demand from the growing population. At the same time, whereas the country is well endowed with iron ore deposits, there is limited exportation of iron and steel products partially owing to limited beneficiation. With the country's population projected to reach close to 70 million people by 2040 , it is thus imperative to develop the iron and steel industry so as to meet the projected demand.

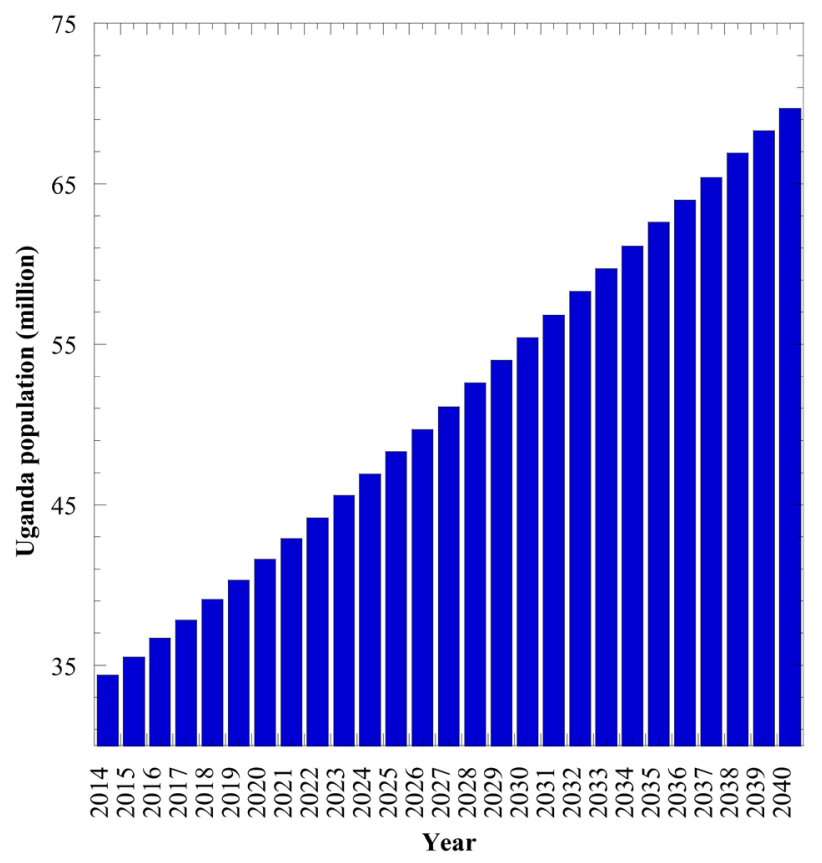

Figure 1. Trend of projected population growth in Uganda. 


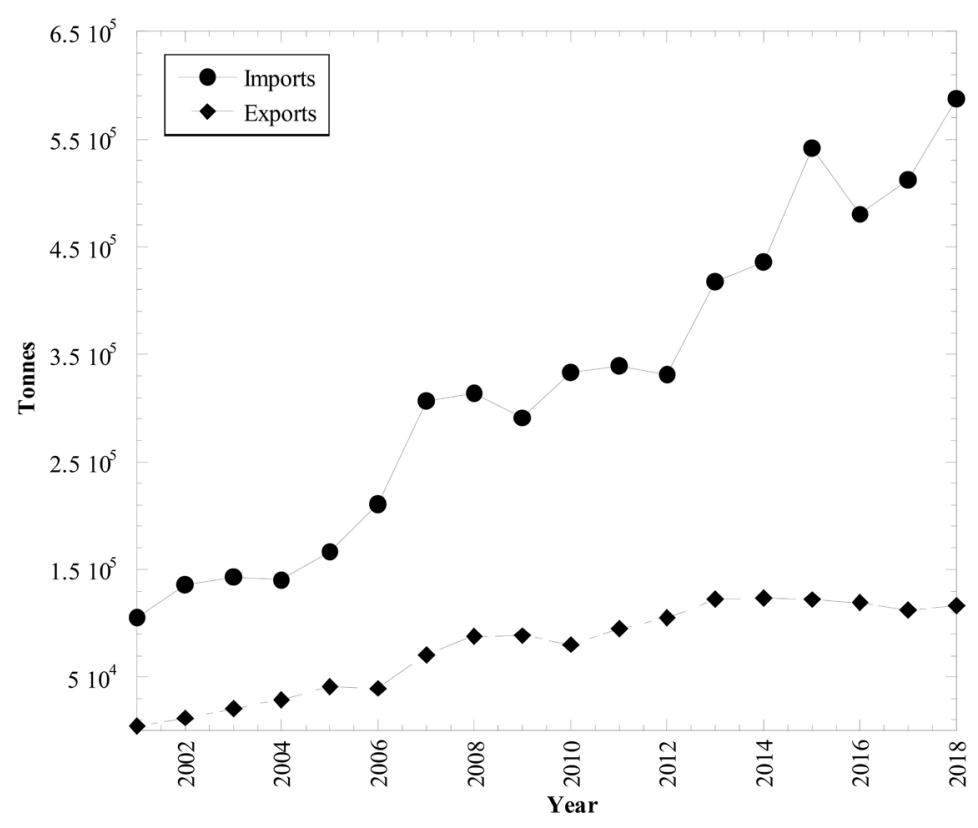

Figure 2. Trends in the import and export of iron and steel in Uganda (2001-2018).

\subsection{Modelling of Uganda's Iron and Steel Value Chain}

Currently, Uganda's production of iron and steel products stands at 530,000 tonnes per annum (tpa), which is $35 \%$ of the installed capacity. Of these, 210,000 tonnes is liquid steel production, which is mainly produced through scrap smelting in the induction furnaces. Using the available production data and planned individual company interventions over the years, a Capability Model of the iron and steel chain, year by year was developed up to 2024 in order to keep it reliable based on the expected infrastructural developments and foreseen changes of the industry in this timeframe.

Figure 3 gives the steel projections coming out of the Capability Model, highlighting the country's liquid steel and the iron and steel products' production.

It can be observed that liquid steel production can be increased from the current level of 210,000 tonnes to 1.4 million tpa by 2024 . This optimistic view was based on the assumption that Uganda will take advantage of the iron ore resources presently available in the country and the natural gas from Tanzania to produce liquid steel (Uganda signed a Memorandum of Understanding with Tanzania in August 2018 to construct a natural gas pipeline from Tanzania for the supply of gas for industrial and domestic purposes). Furthermore, the significant projected growth of the population is envisaged to support the growth-trend of the iron and steel industry and reach the expected ramp up.

By implication, the projected significant growth in Uganda's population is likely to result in an increase in the demand of steel which will be a consequence of a strong development based on important measures of industry sustenance and infrastructure investments. The overcapacity presently installed in the existing plants and the presence of the new scheduled plants ( 2 plants plan to start 
sponge iron production by end of 2021) are promising signals for a rapid increase in steel production to meet the projected per capita values indicated in Figure 4 (Capability Model projections).

In order to compare the assumptions included in the Capability Model year by year for the iron and steel industry growth, an Economic Model was developed based on historical country data. It assesses the impact of iron and steel value chain on GDP without considering specific disruptive measures for a fast development of the industry.

Table 1 gives the three stage least squares results obtained from the model that uses the country data. The three endogenous variables of consumption of steel $\left(c_{-}\right.$steel $\left._{t}\right)$, consumption of other goods $\left.\left(c_{-} \text {others }\right)_{t}\right)$ and investment in the steel sector (inv_steel $I_{t}$ ) and the corresponding parameter estimates of the exogenous variables and the goodness of fit values are given in Table 1.

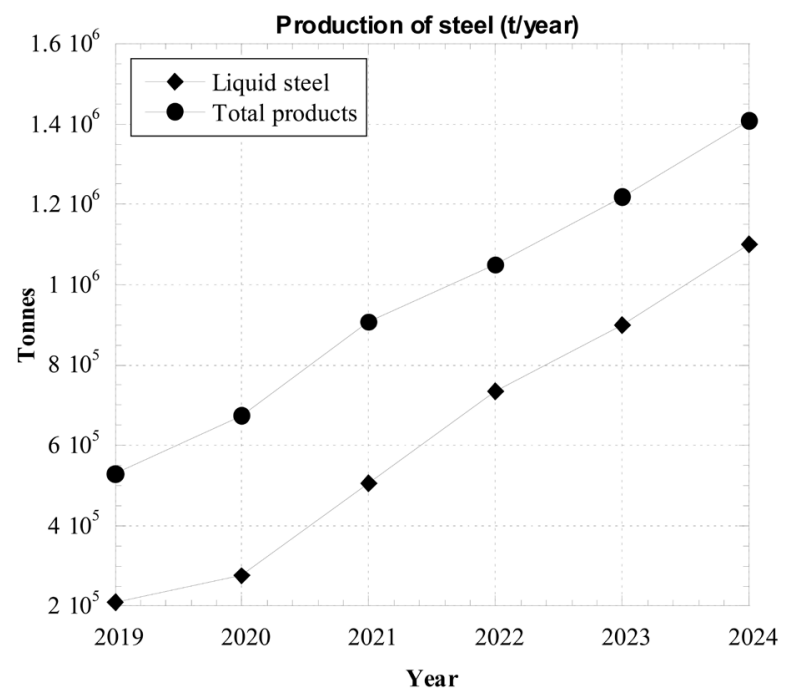

Figure 3. Projected Steel Production in Uganda by 2025.

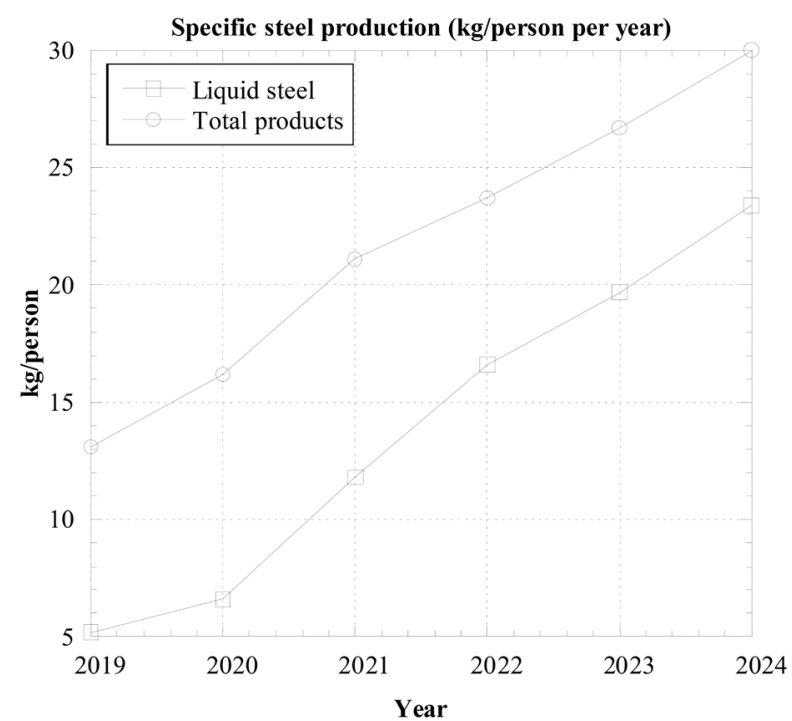

Figure 4. Projected specific steel production in Uganda by 2025. 
Table 1. 3 Stage least square estimation.

\begin{tabular}{|c|c|}
\hline \multicolumn{2}{|c|}{ Consumption of steel } \\
\hline Exogenous variables & 3SLS Coefficients \\
\hline GDP & -0.0092425 \\
\hline Population & $20.35363^{*}$ \\
\hline Consumption of steel (time $t-1$ ) & 0.1051833 \\
\hline Net export of steel & $-1.314868^{\star * *}$ \\
\hline Government expenditure & -0.0118188 \\
\hline Constant & $-3.71 \mathrm{e}+08^{*}$ \\
\hline $\mathbf{R}^{2}$ & 0.9335 \\
\hline \multicolumn{2}{|c|}{ Consumption of other goods } \\
\hline Exogenous variables & 3SLS Coefficients \\
\hline CPI & $8.06 \mathrm{e}+07^{\star * *}$ \\
\hline GDP per capita & $1.05 \mathrm{e}+07^{* * *}$ \\
\hline Net export of other goods & $-0.2745209^{*}$ \\
\hline Constant & $-9.04 e+08$ \\
\hline $\mathbf{R}^{2}$ & 0.9918 \\
\hline \multicolumn{2}{|c|}{ Investments in the steel sector } \\
\hline Exogenous variables & 3SLS Coefficients \\
\hline Real Interest Rate & 35833.75 \\
\hline Total Investments (time $t-1$ ) & $0.0376584^{* * *}$ \\
\hline Constant & $3.03 e+07^{\star *}$ \\
\hline $\mathbf{R}^{2}$ & 0.9415 \\
\hline
\end{tabular}

${ }^{* *}$ Significance level $=0.01,{ }^{*}$ Significance level $=0.05,{ }^{*}$ Significance level $=0.10$.

The model was forecasted for 5 years (2020-2025) and the results are shown in Figures 5-10. The graphs show that the model predictions fit with the production of steel, specific consumption of steel, private investment in the steel sector and GDP.

Figure 5 shows that the model results (forecasted) fit well with the actual historical steel production trends (actual) from 2001 to 2019.

Figure 6 shows the enlarged part of Figure 5 for the years 2019 to 2024 and the prediction shows a general overall increase over this period. Even though there is an initial fluctuation between 2020 and 2022, there is on average a distinctive steel production growth over the next 5 years. The initial fluctuation is due to both the model, which follows a cyclical economic pattern, and to a possible temporary phase where the industry faces the conversion of its production lines because of the new investments.

Similar to Figure 5, Figure 7, shows how the model results (blue dotted curve) fit with the actual historical data (orange curve) as far as per capita steel con- 
sumption is concerned. It should be noted that the specific consumption of steel refers to apparent values of consumption as opposed to the figures reported in the Capability Model.

Figure 8 is the enlarged projected part of the specific steel consumption over the period 2019 to 2024 . It shows that consumption is reaching a steady value because its increase is balanced by the fast growth of the country's population.

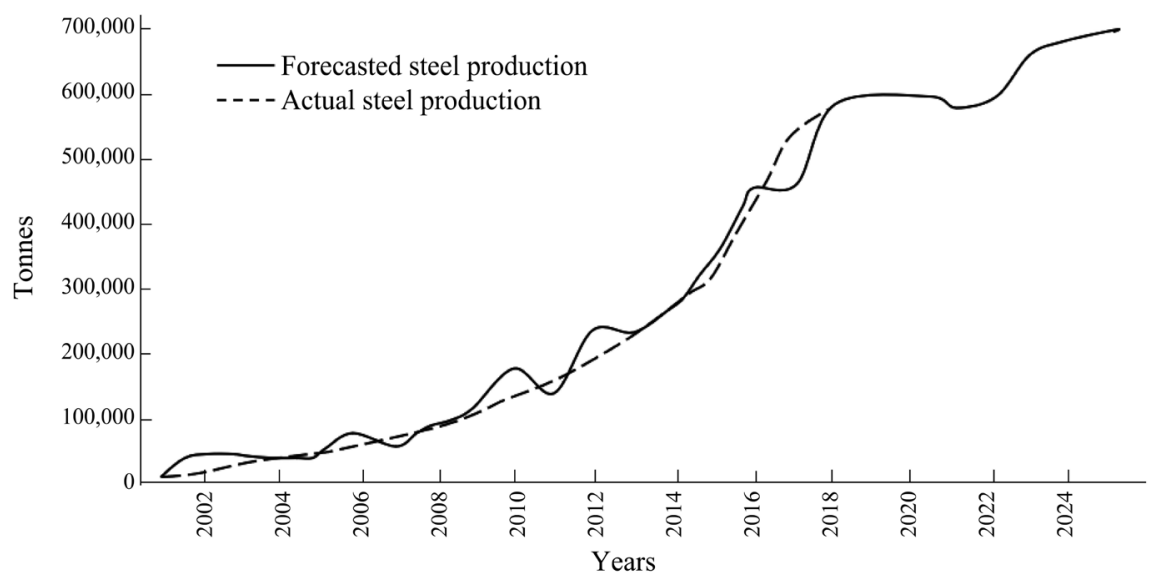

Figure 5. Steel production as forecasted by the economic model.

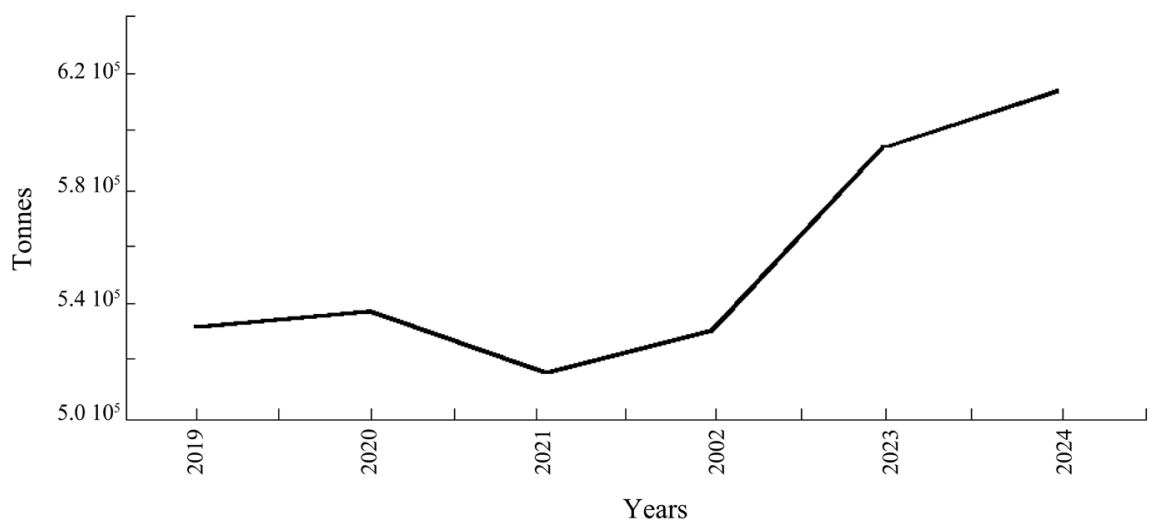

Figure 6. Steel production (extracted for the forecasted years only).

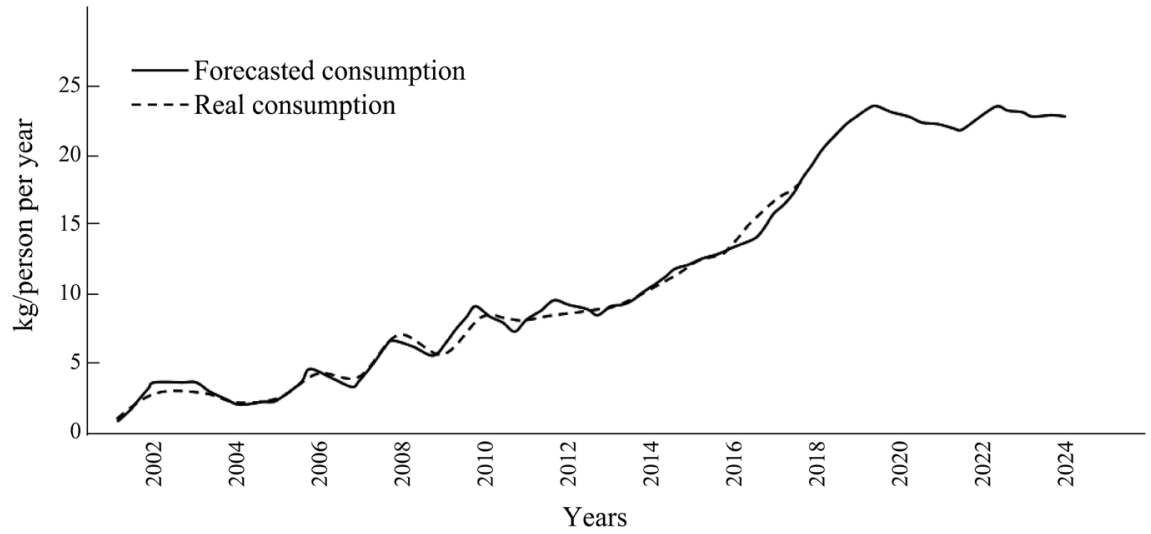

Figure 7. Apparent specific steel consumption per person each year. 


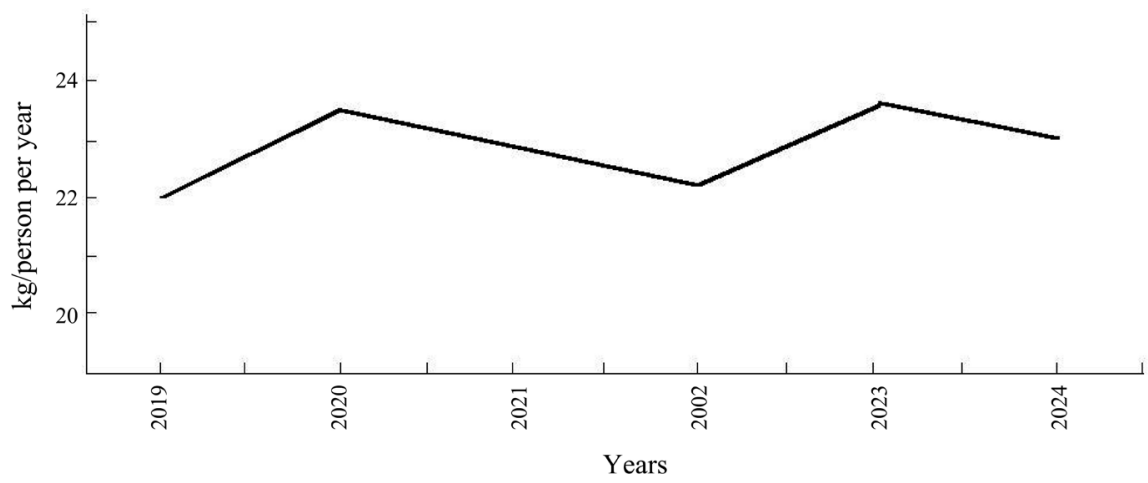

Figure 8. Forecasted specific Uganda steel consumption per person each year.

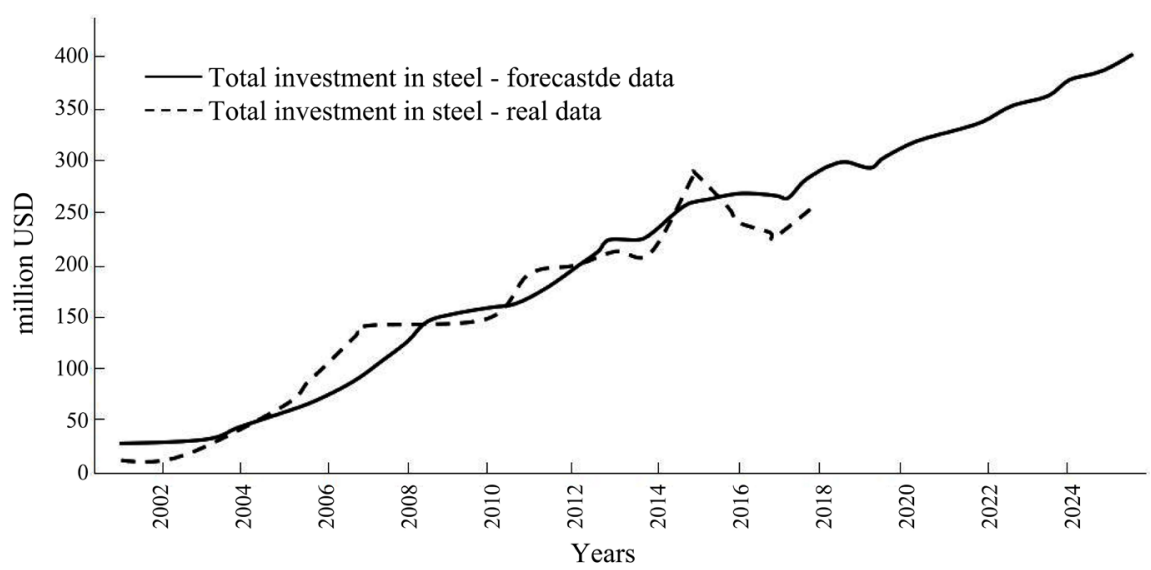

Figure 9. Graph of Uganda Private Investments Steel Sector forecast.

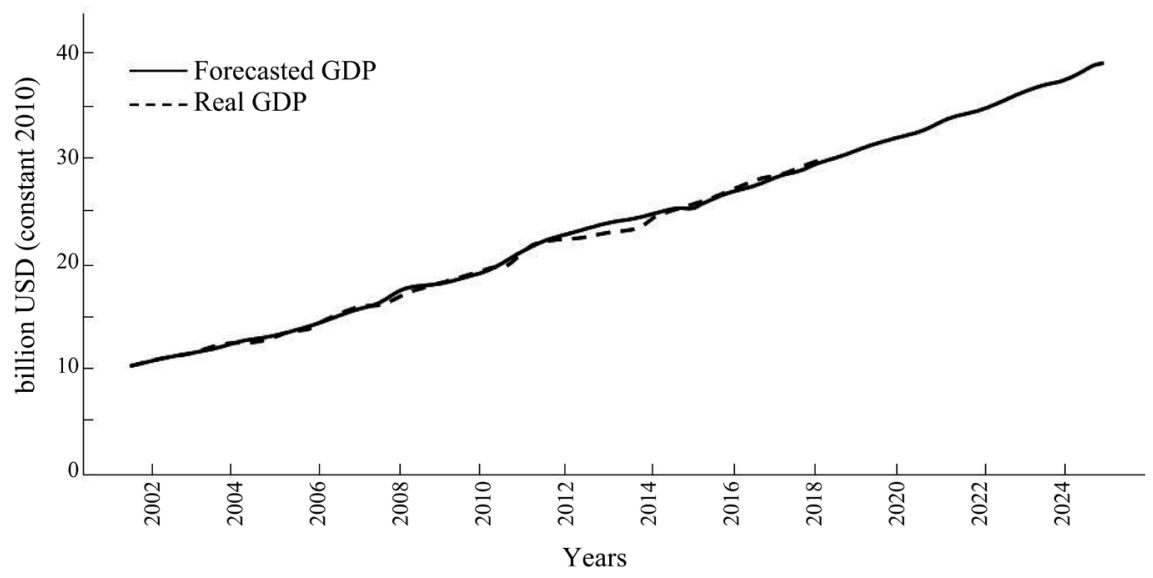

Figure 10. Forecasted GDP growth.

Population data are generally referred to people that consume the steel while available data for Uganda are referred to any age from child to elderly people. For this reason, the curve is not completely representative since children make up the majority of the population in Uganda (50\%).

Figure 9 shows the graph of total investments in the metal sector. Considered under investments over the past years were; data on bank loans to the metal sector, foreign direct investments and local private investments. It can be observed 
that the model prediction averages around the actual trends of investment over the years, which gives credence to the model prediction over the planning period of 2020-2025.

Figure 10 shows a steady increase of GDP up to 2025 reaching a value of about USD 40 billion. Again, the model seems particularly fitting the historical figures.

In order to get an overall final evaluation of the future steel market in Uganda the following aspects must be taken into consideration:

1) The results of the economic model.

2) The information collected from the steel players and the related Capability model.

3) The steel market situation of similar countries worldwide.

\subsection{Economic Model versus Capability Model Output}

Figure 11 gives the comparison of steel production given by the economic model (i.e. the situation of the sector's natural growth without any targeted interventions) versus the capability model taking into consideration the new plants start-up (as anticipated by the key players' visits) and the country's boosted economic growth.

It can be observed from Figure 11 that if the country is to achieve its development targets for the iron and steel industry as per the Uganda Vision 2040 (National Planning Authority, 2013) targets, there is need for some interventions to be made to boost its growth.

The economic model is a precise instrument to forecast the trend of development of the industry. It was set on historical values, country economy parameters and assumptions, which can be eventually modified to verify alternative scenarios. The considered variables of the model have the proper goodness of fit,

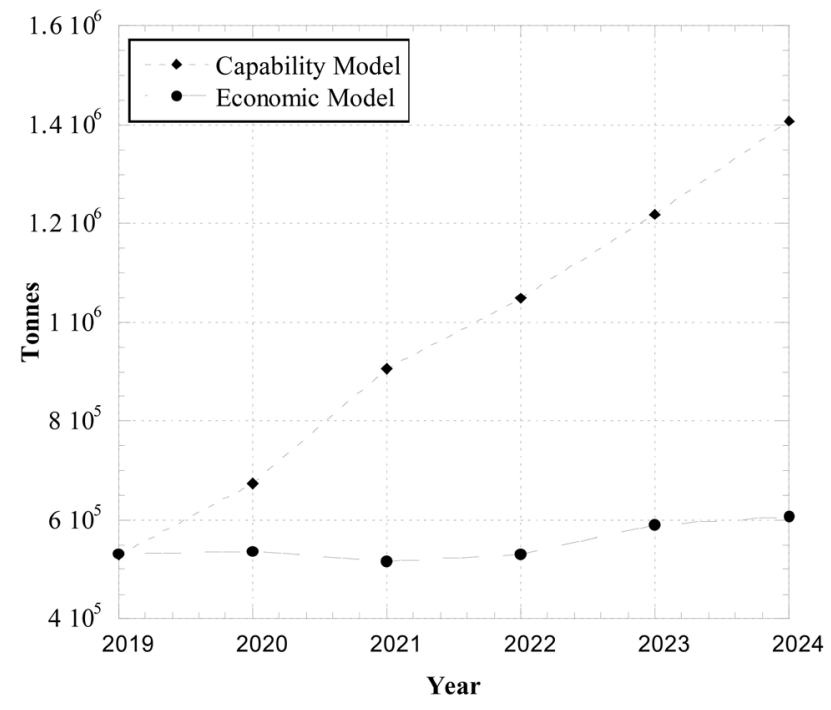

Figure 11. Steel production comparison between the Economic model and the Capability model. 
showing accuracy of the model prediction. However, the economic model does not consider some of the country specific situations, like rate of industry development, which may develop at a faster rate when compared to the model provision. Particularly important, is the overcapacity of the actual key players in Uganda, which allows for immediate supply of additional steel once the economic situation calls for more steel product requirements without the need for waiting for further investments in new equipment.

Government involvement in the development of the industry will accelerate the provision of the necessary and required measures to develop liquid steel production, which can be achieved through implementing proper policy on import of semi-finished products and facilitation of investments in the sector, among other measures. If these measures are backed up by general development of the country's economy and infrastructure (particularly transport), the optimistic scenario of steel production trend showed in Figure 3 could become a reality.

\section{Conclusion}

There is significant evidence that Uganda is capable of increasing the liquid steel production from the current level of 210,000 tonnes to 1.1 Million tpa by 2024 . This is largely premised on the fact that by prioritizing public sector investment in the steel industry, government will provide the catalytic resources to nudge the private sector to take advantage of the abundant iron ore resources available in country. Besides, supported by natural gas from Tanzania coming through South Western Uganda as well as the increased population and demand for steel products, the production of steel in Uganda is a viable enterprise. The overcapacity presently installed in the existing plants and the presence of the new scheduled plants are promising signals for a rapid increase in steel production to meet the projected per capita values. This is further supported by the economic model forecasts on future production levels. Government should work towards implementing a raft of policy measures especially regarding importation of semi-finished steel products, facilitation of investments in the iron and steel sector, as this, backed up by general development of the country's economy and infrastructure (particularly transport and electricity), can lead to the projected potential of the industry to be achieved.

\section{Funding}

This work was supported by the European Union under a project titled, "Technical Assistance to the National Planning Authority, including a Feasibility Study for Establishing a Comprehensive Iron and Steel Industry in Uganda (Specific Contract Nr. 2019/406-879)".

\section{Conflicts of Interest}

The authors declare no conflicts of interest regarding the publication of this paper. 


\section{References}

Banks, F. E. (1979). The "New" Economics of Iron and Steel. Resources Policy, 5, 95-103. https://doi.org/10.1016/0301-4207(79)90003-5

Dervis, K., de Melo, J., \& Robinson, S. (1989). General Equilibrium Models for Development Policy (English). Washington, D.C.: World Bank.

Gunning, J. W., \& Keyzer, M. A. (1995). Applied General Equilibrium Models for Policy Analysis. Handbook of Development Economics, 3, 2025-2107. https://doi.org/10.1016/S1573-4471(05)80007-5

Hashimoto, H. (1983). A World Iron and Steel Economic Model: A Projection for 1980-1995. Journal of Policy Modeling, 5, 379-396.

https://doi.org/10.1016/0161-8938(83)90004-2

International Trade Centre (2019). Trade Map-International Trade Statistics. https://www.trademap.org/tradestat/Product_SelCountry_TS.aspx?nvpm=1\%7c800\%7 c\%7c\%7c\%7cTOTAL\%7c\%7c\%7c2\%7c1\%7c1\%7c2\%7c2\%7c1\%7c1\%7c1\%7c1\%7c1 https://www.trademap.org/tradestat/Country_SelProductCountry_TS.aspx?nvpm=1\%7c8 00\%7c\%7c\%7c\%7cTOTAL\%7c\%7c\%7c2\%7c1\%7c1\%7c1\%7c2\%7c1\%7c2\%7c1\%7c\%7c1

Jensen, S. E., Pedersen, L. H., Rutherford, T. F., \& Glenn, W. H. (2000). Using Dynamic General Equilibrium Models for Policy Analysis (Contributions to Economic Analysis). Holland: North Holland.

Katrak, F. E. (2008). Iron and Steel, Future of. In K. H. J. Buschow et al. (Ed.), Encyclopedia of Materials: Science and Technology (pp. 4292-4295).

https://doi.org/10.1016/B0-08-043152-6/00753-1

Muwanguzi, A. J., Sebukeera, H., Ajidiru, R., Guloba, A., Rukenzo, G., \& Muvawala, J. (2020). The Prospects of Uganda's Iron Ore Deposits in Developing the Iron and Steel Industry. Journal of Minerals and Materials Characterization and Engineering, 8, 316-329. https://doi.org/10.4236/jmmce.2020.84019

National Planning Authority (2010). National Development Plan (2010/11-2014/15). Kampala: National Planning Authority.

National Planning Authority (2013). Uganda Vision 2040. Kampala: National Planning Authority.

National Planning Authority (2015). Second National Development Plan (NDPII) 2015/162019/20. Kampala: National Planning Authority.

Ohanian, L. E., Prescott, E. C., \& Stokey, N. L. (2009). Introduction to Dynamic General Equilibrium. Journal of Economic Theory, 144, 2235-2246. https://doi.org/10.1016/j.jet.2009.09.001

Ruth, M. (2004). Steel Production and Energy. In C. Cleveland (Ed.), Encyclopedia of Energy (Vol. 5, pp. 695-706). https://doi.org/10.1016/B0-12-176480-X/00371-5

Shantayanan, D., \& Delfin, S. G. (1998). The Simplest Dynamic General-Equilibrium Model of an Open Economy. Journal of Policy Modeling, 20, 677-714. https://doi.org/10.1016/S0161-8938(98)00011-8

Stephen, L. B. (1997). Changing Pattern of Trade in the World of Iron Ore and Steel Market: An Econometric Analysis. Journal of Policy Making, 19, 237-251.

https://doi.org/10.1016/S0161-8938(96)00049-X

The Iron Ore of the Earth (1967). Earth Science Reviews, 3, A173-A174. https://doi.org/10.1016/0012-8252(67)90301-7

Uganda Bureau of Statistics (2019). Statistical Abstract. Kampala: Uganda Bureau of Statistics. https://www.ubos.org/wp-content/uploads/publications/01_20202019_Statistical_Abstr act_-Final.pdf 
William, H. G. (2002). Econometric Analysis (5th ed.). New Jersey: Prentice Hall.

World Bank (2020a). Data Bank: World Development Indicators.

https://databank.worldbank.org/reports.aspx?source=2\&Topic $=21$

World Bank (2020b). World Bank Open Data. https://data.worldbank.org/

World Steel Association (2008). Fact Sheet: Energy—Steel and Energy.

World Steel Association (2016). Fact Sheet: Steel and Raw Materials.

World Steel Association (2020a). 2020 World Steel in Figures.

https://www.worldsteel.org/en/dam/jcr:f7982217-cfde-4fdc-8ba0-795ed807f513/World \%2520Steel\%2520in\%2520Figures\%25202020i.pdf

World Steel Association (2020b). World Steel in Figures.

https://www.worldsteel.org/steel-by-topic/statistics/World-Steel-in-Figures.html 